\title{
Study of Biology and Effective Management of Gram Pod Borer, Helicoverpa armigera Hub on Field Pea
}

\author{
Gulab Singh ${ }^{1}$, R. K. Dwivedi ${ }^{1}$ and Anurag Shukla ${ }^{2^{*}}$ \\ ${ }^{1}$ Dept. of Entomology, ${ }^{2}$ Dept. of Plant Pathology, C.S.A.U.A.T, Kanpur-2, India \\ *Corresponding author
}

\section{A B S T R A C T}

\begin{tabular}{l} 
K e y w o r d s \\
Helicoverpaarmiger \\
a, Cow urine, \\
Incremental Cost \\
Benefit Ratio, \\
Lantana leaf, \\
Efficacy, Neem \\
Article Info \\
\hline $\begin{array}{l}\text { Accepted: } \\
\text { 18 August } 2020 \\
\text { Available Online: } \\
\text { 10 September } 2020\end{array}$ \\
\hline
\end{tabular}

The experiment was conducted to study of biology of $H$. armigera in relation to abiotic factors (temperature, relative humidity, rainfall etc.), to evaluate the efficacy of some botanicals and organic compounds against $H$. armigeraand workout the economics of different treatments with Incremental Cost Benefit Ratio (ICBR), H. armigera on field pea in Rabi 2018-19. Result showed that the population of H.armigera appeared on 4th week of November (1.15 larvae/ 5plant) i.e. 47th Standard Meteorological Week (SMW) \& reach its peak (15.10 larvae/ 5plant) during 52nd SMW i.e. last week of December. The pest population gradually decreased (0.8 larvae/ 5 plant) in the 3rd week of February i.e. 7 th SMW due to the reason of crop maturity. Regarding efficacy of treatments cow urine + neem leaf proved most effective which was closely followed by cow urine + tobacco leaf and cow urine + lantana leaf. Maximum yield i.e. 21 . 40q/ha was given by cow urine + neem leaf which was closely followed by cow urine + tobacco leaf and cow urine + lantana leaf. ICBR of cow urine i.e.1:15.5 was the highest followed by cow urine +neem leaf having ICBR 1:13.52. Similar trend in percent increased yield over control was observed in this investigation.

\section{Introduction}

Field Pea, Pisum sativum L. is an important leguminous vegetable crop \& mostly grown in all states of the country during Rabi season and because of its taste, nutritive value, fast growth and high yield this crop is patronized throughout the world. It is used as vegetable purpose as well as pulse (10). Insect pests are probably the main factor limiting the legume production. Gram pod borer, H.armigera Hubner, (Lepidoptera: Noctuidae) is one of the most devastating crop pest worldwide (9).
Sixty cultivated and sixty-seven wild host plants attacked by $H$. armigera have been recorded from India (2). In India, the extent of losses due to $H$. armigerain chickpea is up to $27.9 \%$ in northwest plain zone, $13.2 \%$ in north east plain zone, $24.3 \%$ in central zone and $36.4 \%$ in south zone (4). The crop has been noted to suffer an avoidable loss of 9 to $60 \%$ (12). The problem of this pest is magnified due to its direct attack on fruiting structures, voracious feeding habits, high mobility, fecundity and multivoltine overlapping generations (8) and (11). 


\section{Materials and Methods}

The present investigation was conducted during Rabi season of 2018-2019 at Student Instruction Farm (SIF) in Chandra Shekhar Azad University of Agriculture \& Technology, Kanpur- 208002 (U.P.). It lies between $26.26^{\circ} \mathrm{N}$ latitude and $80.24^{\circ}$ east longitudes at an altitude of 125.9 meters above mean sea level.

\section{General climatic information of experimental site}

Kanpur has subtropical and semi-arid climate with hot summer and severe cold winter. The winters are severe with a minimum temperature of about $5{ }^{\circ} \mathrm{C}$ with occasional ground frost. In summer the temperature often goes up to 40 to $45^{\circ} \mathrm{C}$ in the month of May and June. The mean precipitation is about 800 $\mathrm{mm}$ of which about 80-90 per cent is received during July to September.

\section{Soil of the experimental field and} Preparation of the field

The soil of the experimental field was sandy loam with an average fertility level. Field was ploughed twice with the help of tractor mounted disc harrow. Each ploughing was followed by leveling with the help of leveler with pre sowing irrigation.

\section{Layout and sowing of experiment}

The field trial with chickpea variety KPMR522 in randomized block design in a plot measuring $3 \times 6 \mathrm{~m}$ area and 8 treatments including control with 3 replications was laid out on October 20, 2018 in a well prepared field. Seed was sown@ 100kg/ha.

The furrows were opened with the help of furrow opener adjusted at a row distance of $30 \mathrm{~cm}$ and plant to plant of $5 \mathrm{~cm}$ apart. The furrows were covered with soil and field was made smooth after completing the total sowing.

\section{Fertilizer application}

Recommended dose of $20 \mathrm{~kg} / \mathrm{ha} \mathrm{N}$, and 40 $\mathrm{kg} / \mathrm{ha} \mathrm{P}_{2} \mathrm{O}_{5}$ were applied for good crop production. Total dose of the nitrogen as starter dose which can meet plant requirement before the formation of nodules and total quantity of phosphorus were applied as basal at the time of final field preparation. All the fertilizers are drilled in furrows at a depth of 7-10 centimeters.

\section{Weeding}

First weeding was done at 15 days after germination with the help of "Khurpi" and second weeding was done when the crop was 35 days old.

\section{Identification}

The adult of Helicoverpa armigera Hub.is a typical stout built noctuid moth with a wing span of 30 to $40 \mathrm{~mm}$, and colour varying from olive gray to red brown. Fore wings are dark speck and dark area found at outer margin. The hind wings are white with dark veins and a broad blackish band along the outer margin.

\section{Life Cycle of Helicoverpa armigera}

The moth begins ovipositing on pea plant at the seedling stage but this behavior is checked by the adverse climatic and geographical conditions (13). The population peaks were observed in different months of the year. The population peaks generally corresponds to the full bloom and pod formation stage of Chickpea (6). This is active from October to April and has 7-8 overlapping generations. Each female lays eggs singly on tender parts of the plants. A single female may lay as 
many as 740 eggs in 5 days. They hatch in 6 days in November to April. The larval population of the pest can be seen initially on the young leaves, under heavy infestation young shoots are also attacked and the plants become weak. The young larvae feed on the foliage for some time and later bore into the pods and feed on the developing grains with their bodies hanging outside. They move from pod to pod and full feeding in 13-19 days.

\section{Observation Recorded}

\section{Larval observations}

Larval duration: It was taken from the hatching of eggs till pupation.

Larval weight: It was observed on the fifth instar.

Full size: It was observed on the fifth instar.

\section{Pupal observations}

Pupal duration: It was taken from the starting of pupation till adult emergence.

Pupal weight: It was taken few days after pupation.

Female emergence per cent $=\frac{\text { No. of female emerged X } 100}{\text { Total no. of adult emerged }}$

Male emergence per cent $=\frac{\text { No. of male emerged X } 100}{\text { Total no. of adult emerged }}$

\section{Growth and Fitness Index}

The larval and pupal growth index and the fitness index were calculated using the following equations

Larval growth index $=\frac{\text { Pupation per cent }}{\text { Larval period (days) }}$
Pupal growth index $=\frac{\text { Emergence per cent }}{\text { Pupal period (days) }}$

Fitness index $=\frac{\text { Pupation per cent } X \text { pupal weight }}{\text { Larval period }+ \text { pupal period }}$

\section{Results and Discussion}

The present study are supported by (14), who stated that the larval population of $H$. armigera occurred on chickpea throughout its growth phase, being low at the vegetative and flowering stage and high at the grain development stage. There were two larval peaks, first between 47-50 standard weeks and second between 11-15 standard weeks (Table 1).

The present findings are supported by (1) who reported that cow urine and its combination with neem leaf, lantana leaf was effective in reducing the population of Helicoverpa armigera Hub. in chickpea crop. (7) who studied four botanicals viz., mahogany oil, mahogany seed extract, tobacco leaf extract and neem seed kernel extract were tested for their efficacy against H.armigera. The lowest fruit infestation, both by number and weight, was observed in neem seed kernel extract $(27.15 \%, 22.29 \%)$ treated plot which was statistically similar to tobacco leaf extract $(27.71 \%, 23.31 \%)$ treated plot.

(5)studied bio-efficacy of different botanicals against thrips, Scirtothrips dorsalis in Bt cotton. Among the nine botanicals evaluated against $S$. dorsalison Btcotton, neem seed kernel extract (NSKE) 5\% found the most effective followed by neem oil 1 per cent, neem leaf extract (NLE) 10 per cent, garlic bulb extract (GBE) 5 per cent and ginger rhizome extract (GRE) 5 per cent with seed cotton yield 2304, 2295, 2275, 2252 and 2238 $\mathrm{kg} / \mathrm{ha}$, respectively. The highest (1: 7.34) ICBR obtained with the treatment of NLE followed by NSKE (1: 6.20) and GBE (1: 
4.54).(3)conducted an experiment to study the efficacy of botanical insecticides against tomato fruit borer, Helicoverpa armigera Hub. on tomato, Lycopersicon esculentum Mill, during 'rabi' season of 2013 - 2014. The result revealed that the maximum reduction of $100 \%$ was recorded in the plot treated with Chloropyriphos 40 EC $0.2 \%$ and it was found significantly superior over all treatments. Next better treat-ments were of botanicals i.e., Nimbicidine $0.4 \%$, Neem oil $5 \%$ and Neemazol $0.4 \%$ with $83.33,77.78$ and $72.22 \%$ of fruit damage respectively. Treatments followed to these were NSE, Tobacco leaf extract, leaf extract of lantana camara and control with 66.67, 66.67, 55.56and $0.00 \%$ fruit damage reduction respectively. The data on cost benefit ratio of (1:21.59) was recorded in Chloropyriphos and proved to be most effective among the treatments. However, nimbicidine recorded second highest benefit cost ratio of (1:19.23) followed by Neem oil, (1:18.18), NSE (1:17.75), neemazol (1:16.48), tobacco leaf extract (1:15.95) and leaf extract of lantana camara (1:15.43).

The monetary gain from the treatment was determined by the calculating the cost of production and value of saved yield. The highest net income (Rs. 36465/ha) was found in the treatment, cow urine + neemleaf followed by cow urine + tobacco leaf (Rs 29185/ha). The lowest net income (Rs. 17582/ha) was obtained from lantana leaf extract.

Based on ICBR, the treatment with cow urine was found most economic treatment which gave the maximum benefit (1:15.50) as compared to all other treatments. The next profitable treatment was cow urine + neem leaf (1:13.52) based on higher cost-benefit ratio. All treatments were found cost effective over the control.
It may be concluded from the present investigation, that the response of treatments in terms of per cent reduction of larval population over control during Rabi season 2018-19 is as under-

Cow urine+neem leaf $>$ cow urine+tobacco leaf >cow urine+lantana leaf >neem leaf extract >cow urine >tobacco leaf extract $>$ lantana leaf extract.

The monetary gain from the treatments was determined by the calculating the cost of production and value of saved yield. The highest net income (Rs. 36465/ha) was found in the treatment, cow urine + neemleaf followed by cow urine + tobacco leaf (Rs. 29185/ha). The lowest net income (Rs. 17582/ha) was obtained from lantana leaf extract.

Based on ICBR ratio, cow urine was found most economic treatment which gave the maximum benefit (1:15.50) as compared to all other treatments. The next profitable treatment was cow urine + neem leaf (1:13.52) based on higher cost-benefit ratio. All treatments were found as cost effective over the control.

\section{Acknowledgements}

This research was supported by Department of Entomology Chandra Shekhar Azad University of Agriculture \& Technology, Kanpur.

\section{Compliance with ethical standards:}

The authors declare that they have no conflict of interest. This article does not contain any studies with human participants or animals performed by any of the authors. 


\section{References}

Bijewar A. K., Chouragade V. and Das, S.B. (2018). Field efficacy of plant leaf extracts, cow urine and in combination against pod borer complex in pigeonpea (Cajanus cajan (L) Millsp.). Journal of Entomology and Zoology Studies. 6(5): 342-347.

Karim S. (2000) Management of Helicoverpa armigera. Pakistan Journal of Biological Science; 3:1213-1222.

Kumar, A., Rai, M.K. and Singh, S. S. 2010.Efficacy of neem products vis-à-vis triazophos for management of soybean stem borers. Annals of Plant Protection Science 18 (1): 136-140.

Lateef SS, Reed W. (1983) Review of crop losses by insect pests in pigeon pea internationally and in India. In Proceedings of the International Seminar on Crop losses due to insect pests (Eds.) by Rao. B.H.K. and Murthy, K.S.R.K. 7-9 January, 1983. Entomological Society of India, Hyderabad, A.P. India, 1983, 284291.

Padaliya S. R., Thumar R.K., Pipaliya G.K. and Bhagora J.K. (2018). Bio efficacy of different botanicals against thrips, Scirtothrips dorsalis (Hood) infesting bt cotton. International Journal Current Microbiology Applied Science, 7(7): 2893-2903.

Patel C.C. and Koshiya D.J. (1999). Population dynamics of gram pod borer, Helicoverpa armigera (Hubner) on cotton,pigeon pea and chickpea crop host. Gujrat Agriculture University Research Journal, 24: 62-70.
Raghvendra, K.V., Gowthami, R., Lepakshi, N.M., Dhananivetha, M., Shashank, R., 2016.Use of Botanical, by farmers for integrated pest management of crops in Karnataka, Asian Agriculture History. 20(3): 173-180.

Sarode SV. (1999)Sustainable management of Helicoverpa armigera Hubner. Pestology.; 13(2):279-284.

Sigsgaard L, Greenstone MH, Duffield SJ. (2002) Egg cannibalism in Helicoverpa armigera, Hubner. sorghum and pigeon pea. Biological Control; 47:151-165.

Singh, H. and Joshi. B.S. (1970).Pulses of India ICAR, New Delhi.

Singh Y. S., Ningthoujam K., Nakambam S., Thakur N.S.A., T Rajesh, Tombisana R.K., and Balasubramanian P. (2019) Studies on the biology of Helicoverpa armigera on different semi-synthetic diet. Journal of Entomology and Zoology Studies. 7(1): 709-712.

Sithanantham S, Rao VR, Ghaffar MA. (1983) International review of crop losses caused by insects on chickpea. In proceedings of the national seminar on crop losses due to insects pests (eds.) by, B.H.K. Rao and K.S.R.K. Murthy, Hyderabad, A.P., India., 269-283.

Tahhan, O., Sithanantham, S., Hariri, G., and Reed, W. (1982).Heliothis species infesting chickpeas in northern Syria. International chickpea News letter., 6:21

Yadav C.P. and Lal, S.S. (1998). Relationship between certain abiotic and biotic facters and the occurrence of gram pod borer, Helicoverpa armigera (Hubner) on chickpea, Entomon 13 (3\&4): 269-273.

\section{How to cite this article:}

Gulab Singh, R. K. Dwivedi and Anurag Shukla. 2020. Study of Biology and Effective Management of Gram Pod Borer, Helicoverpa armigera Hub on Field Pea. Int.J.Curr.Microbiol.App.Sci. 9(09): 2725-2729. doi: https://doi.org/10.20546/ijcmas.2020.909.339 